\title{
Analysis of Factors Affecting Use of Pre-Emergence Wheat Herbicides in Kenya
}

\author{
William Bett Kiprotich Samuel Otieno John \\ Moi University, Kenya, School of Agriculture and Natural Resources
}

\begin{abstract}
Agrochemicals are used principally to control weeds and pests in agriculture. Wheat production in Kenya has not been sufficient despite concerted efforts by agrochemical companies to market agrochemicals to farmers. The study aimed at establishing the determinants of use of pre-emergence wheat herbicides among the wheat farmers in Kenya. The study was conducted in Uasin Gishu County. Stratified random sampling was used to sample 164 wheat farmers. Data collection was done using a well structured questionnaire administered to the wheat farmers. Logit regression technique was used to determine the association between determinants of use of pre-emergence wheat herbicides among the wheat farmers. The results show that education level, land tenure, average income, extension services, market information and credit access variables were statistically significant. The study recommended improvement of extension services to wheat farmers and increased accessibility of credit facilities by financial institutions at affordable prices. It is also necessary to have further research on how extension services can enhance wheat production.
\end{abstract}

Keywords: Herbicides, Pesticides, Pre-emergence

DOI: $10.7176 / \mathrm{JESD} / 10-6-12$

Publication date:March $31^{\text {st }} 2019$

\section{I.INTRODUCTION}

Agrochemicals, also known as pesticides or crop protection chemicals, are chemicals manufactured from a wide range of organic and inorganic chemicals and used to control pests, weeds, insects and fungi. The global market for agrochemicals was valued at around US\$ 50 billion in 2008, with about two thirds (US\$ 35 billion) of this coming from crop protection products and one third (US\$ 15 billion) from non-crop uses, such as forestry, public health and industrial uses (Uaine et al., 2009). Agrochemicals are used principally to control weeds and pests in agriculture. The market for this major application was valued, at the end-user level, at around US\$ 31.25 billion in 1998 (Bahadur, 2004). Agrochemicals are also used in a variety of non-crop applications, which are generally higher value-added products. Agrochemicals' global market for non-crop applications, valued at US\$10.5 billion in 1998, included applications in forestry, leisure (such as home, garden and golf courses) and industrial pest control (such as control of vermin and insects, weed control in towns and on railways) (Bahadur, 2004). The noncrop sector is dominated by insecticides (around a half) and non-selective herbicides.

The Pesticides and fertilizers are the primary agrochemicals used by farmers in Kenya. The farmer uses these agrochemicals to control organisms that destroy crops and infest livestock. In addition, fertilizers are needed to replenish soil nutrients and consequently improve the agricultural yield. The public health sector uses pesticides to combat insects and vectors that transmit diseases to humans and animals. Although Kenya's economy is dependent on agriculture, only a third of the land is arable. Enormous amounts of the agrochemicals are imported and extensively used every year. For instance, between 1985 and 1987, Kenya imported agrochemicals worth 1,732.3 million Kenya Shillings (US\$ 69.3 million) (Mugonozza, 2001). The agrochemical industry is an important segment of the Kenya economy. According to the Agrochemicals Association of Kenya (Lai et al., 2015), the industry increased job opportunities and tax revenues to the government. This is evident in the manner in which new products are developed. Other benefits associated with the industry include environmental protection campaigns and credit facilities to farmers. Wheat as a cereal crop is a major user of agrochemicals as compared to other cereal crops. The major chemicals in wheat production include herbicides, fungicides, and insecticides among others.

Agrochemical applications are essential technological means for growing field crops. The most critical technological points in production of grain crops are agrochemical interventions, so that it is essential to reveal and study soundly their impacts (Baniya et al., 2003). Chemical applications are seen by the public to be both harmful to crops and environment. However, appropriate treatments secure high yields and help to reduce serious weed infestations in ecosystems (Teklewold, et al., 2006). Weeds are in permanent competition with crop plants and hence the need for their control. Weed control is essential to establish conditions for optimum crop performance (Khanna, 2012). Soils as the fundamental habitat for any plant growth provide optimal, sub-optimal and hyper-optimal conditions for vegetation in relation with climatic variability (Loevinsohn et al., 2013). Agrochemicals are therefore essential in production so as to provide plants with nutritional deficiencies in soils and also to provide protection from harmful pests and diseases. It is therefore important to evaluate the factors that influence agrochemical applications as well as to study how plant protection treatments can influence crop yields; 
from a purely economical point of view.

Wheat is the second most important cereal crop after maize in Kenya (KARI, 1989) and is becoming an important source of food for both humans and livestock. Wheat production started at the beginning of the $20^{\text {th }}$ century in Kenya, but it was not until 1927 that formal wheat breeding research program was initiated at the Kenya Agricultural Research Institute's (KARI) National Plant Breeding Research Centre (NPBRC) in Njoro, Kenya. Since this program began, many wheat varieties have been released. The demand for wheat and wheat products is growing at 7 percent per annum and only about 50 percent of domestic consumption requirements are being met (Hassan et al., 2016). Increasing population, rapid urbanization, rising income levels, and changing tastes and preferences are major factors contributing towards this demand. Various constraints have contributed to the failure to meet domestic demand and these include erratic and unpredictable climatic conditions, lack of credit among farmers, failure to adopt proper and improved technologies in production as well as failure to invest in agrochemicals which are essential in wheat production.

Wheat production in Kenya has not been sufficient (Sikinyi, 2010). This has continued to happen despite concerted efforts by agrochemical companies to market agrochemicals to farmers. Low use of inputs such as agrochemicals by farmers, due to market constraints that reduce profitability of input use, is one of the factors responsible for the gap between potential and actual yields.

It was thus a matter of concern to establish determinants of use of wheat agrochemicals. The main focus was on the use of pre-emergence wheat herbicides, with the hope of cascading the findings for use in the other sectors of wheat agrochemicals. This is because wheat, being the second most important cereal grain in Kenya after maize, requires a lot of attention. The crop is grown largely for commercial purposes on large scale farms. Wheat production has, however, over the years not been sufficient as Kenya continues to rely on wheat imports to meet domestic demand for wheat and wheat products.

\section{THEORITICAL FRAMEWORK}

Adoption is seen as the first or minimal level of behavioural utilization and innovation. It is an idea, practice, or object; perceived as new by an individual or other units of adoption (Rogers 2003). According to Feder et al, (2015) an innovation is defined as a technological factor that changes the production function regarding which there exists some uncertainty, whether perceived or objective (or both). The uncertainty diminishes over time through the acquisition of experience and information, and the production function itself may change as adopters become more efficient in the application of the technology. They continue to argue that technology adoption may also be viewed from two perspectives. At the micro level, each decision unit must choose whether to adopt the innovation and its intensity of use if adopted. Many adoption studies, they further noted, therefore, examine the factors influencing the firm's or household's adoption decision and may be viewed from a static or dynamic (if learning and experience are incorporated in the decision model) perspective. At the macro level, they noted, the adoption pattern of the whole firm or household population is examined over time to identify the specific trends in the diffusion cycle. "Diffusion studies do not consider the innovation process, but begin at a point in time when the innovation is already in use".

Determinants of adoption are outlined clearly by (Rogers 2003). He outlined them as being dependent on perceived attributes, of which comparative advantage or the degree to which an innovation is perceived better than the idea it supersedes is first taken into account. Other issues of attributes that he outlined are: complexity (the degree to which a practice is perceived as relatively difficult to understand and to adopt, negatively related to its rate of adoption), trialability (degree to which an innovation may be experimented at a limited basis) and compatibility (degree to which sustainable practice is perceived as consistent with the existing values, past experience and needs of potential adopters. Rogers (2003) further described innovation process as a process through which an individual passes from; knowledge to attitude and finally to adopting (indivual or collective, optional or authority). He further pointed out the importance of communication channels in innovation process defining them as interpersonal or mass media, originating from specific or diverse sources. He also defined Social system as norms, network interconnectedness pointing out that these socio-cultural practices and norms can inhibit or drive adoption. He stated that efforts of promotion agent in the past and present are important. The current study drew similarity with this theory to study factors influencing use of pre-emergence herbicides among wheat farmers in Uasin Gishu County.

Rogers (2003) categorizes adopters into: 1) innovators who are educated and venturesome; 2) early adopters who are popular educated and are normally social leaders; 3 ) early majority who are deliberate and have many social contacts; 4) late majority who are very sceptical; 5) laggards who are traditional and normally of lower social economic class. These may end up not adopting the technology. The distribution of these groups follows the familiar bell-shaped curve, when plotted to indicate their features in the relevant population.

To understand agrochemical use, an understanding of derived demand was found to be of significance. This called for indication of direct demand which emulates the following general demand function of perceived variances: 
Where: Dw, stands for demand for Wheat; Px, price of wheat locally; Pm, price of Wheat Flour

Pd-price of fuel; Pa- price of agrochemicals; Pf-price of Fertilizer; Hin-Household income; Hsize- Household size; A-Promotion of wheat products; Pe-Price expectation of wheat consumers and T-Household taste or preferences.

In the same way, supply of wheat in the local Kenyan market is subject to various variables which may determine how much can be produced by the Kenyan farmers. These can be elaborated as follows, in a generalized wheat supply function:

$\mathrm{Sw}=\mathrm{F}(\mathrm{Px}, \mathrm{Pi}, \mathrm{Pm}, \mathrm{Pd}, \mathrm{Pa}, \mathrm{Pf}, \mathrm{N}, \mathrm{Fsize}, \mathrm{A}, \mathrm{Pe}, \mathrm{T} \& \mathrm{G})$

Where: Sw-stands for supply of Wheat; Px- price of wheat locally; Pi- price of imported wheat; Pm-price of wheat flour, Pd- price of fuel; Pa- price of agrochemicals; Pf- price of Fertilizer; N-number of wheat farmers; Fsize-Total area under wheat locally; A, Promotion of wheat products; Pe-Price expectation of wheat consumers; T-technology for use in wheat farming and G-government policy.

The above was considered in light of derived demand. However as postulated earlier, use of pre-emergence herbicides was studied and used a generalized way of understanding the decisions that farmers consider in purchasing all other classes of agrochemicals. Derived demand as used in Uasin Gishu County was suggested to be studied using the following simplified demand function:

$\mathrm{Da}=\mathrm{F}(\mathrm{Px}, \mathrm{Pl}, \mathrm{Cspy}$, Hin, Fsize, A, Pe, T, $)$.

Where:

Da-, stands for demand for Wheat Agrochemicals; Px- price of Agrochemicals; Pl-price Labour; Cspy- cost of spraying agrochemicals; Hin- Household income; Fsize- Total area under wheat locally; A,-Promotional strategies for pre-emergence wheat herbicides and other agrochemicals; Pe- Price expectation of wheat farmers and T- Household taste or preferences.

\section{III.RESEARCH METHODOLOGY}

\section{Study area}

The scope of this study was limited to the analysis of factors influencing use of pre-emergence wheat herbicides in Uasin-Gishu County, Kenya. The County is one of the counties in Rift Valley province. It extends between longitudes $34^{\circ} 50^{\prime}$ and $37^{\prime}$ east and $0^{\circ} 03^{\prime}$ and $0^{\circ} 55^{\prime}$ ' north. The County shares common borders with Trans Nzoia County to the north, Elgeyo-Marakwet and Keiyo Counties to the east, Baringo County to the south east, Kericho County to the south and Nandi County to the west. The county has a total area of $3,327.8 \mathrm{~km}^{2}$ (GOK, 2004).

Administratively, the County is divided into six Sub Counties namely Kapseret, Ainabkoi, Kesses, Soy, Turbo and Moiben. Rainfall in the County is high, reliable and evenly distributed. The average rainfall ranges between $900 \mathrm{~mm}-1200 \mathrm{~mm}$. It occurs between the months of March and September with two distinct peaks in May and August. Dry spells begin in November and end in February. Temperature ranges between $8.4^{\circ} \mathrm{c}$ and $26.1^{\circ} \mathrm{c}(\mathrm{GOK}$, 2010). An estimated 90 percent of the land area in the County is arable out of which about $2,000 \mathrm{~km}^{2}$ is classified as high potential and about $1000 \mathrm{~km}^{2}$ is medium potential. There are four major soil types in the County that are good for agricultural production. These include red loam, red clay, brown clay and brown loam (GOK, 2010).

Agriculture is the main economic activity of Uasin Gishu County. A total of 126,311.2 hectares are under crop production, while 204,000 of the population work in agriculture alone. The main types of crops grown in the region comprise of maize and wheat. The farmers also practise dairy rearing both for subsistence and commercial purpose.

\section{Research design}

The study used a survey design. The survey aimed at collecting data from wheat farmers in Uasin Gishu County in order to determine their current status with respect to use of wheat agrochemicals in the County. Survey design was preferred because it is useful in exploring existing status of two or more variables at a given point in time. Pre-emergence herbicides active ingredients, namely; pendimethalin, chlorsulfuron tribenuron methyl and flufanecet, with different trade names were used. Trade names like Stomp, Glean, Granstar and Tiara, corresponding to the above respectively were used for ease of farmer understanding. These are herbicides used before weeds emerge in a plantation of wheat.

\section{Population, sample size and sampling techniques}

The target population for this study was all wheat farmers in Uasin Gishu County. The County is one of the several counties in Kenya that grow wheat. A sample size of 164 wheat farmers was used in the study and was determined as follows.

$\mathrm{n}=\mathrm{z}^{2} \mathrm{p} \mathrm{q}$

$$
\mathrm{d}^{2}
$$

Where:

$\mathrm{n}=$ the desired sample size $\mathrm{z}=$ the standard normal deviate at 0.1 confidence level $\mathrm{p}=$ the proportion in the target population estimated to have characteristics being measured $\mathrm{q}=1-\mathrm{p}$ 
$\mathrm{d}=$ level of statistical significance set at 0.05 .

The $\mathrm{z}$ - statistic at 90 percent confidence level is 1.282 . Since there was no estimate ,available , of the proportion in the target population that was assumed to have the characteristics of interest (p), 50 percent was used as recommended by Adebiyi and Okunlola, (2013). Therefore, $\mathrm{p}$ was 0.5 . The level of significance, $\mathrm{d}$, was 0.05 . Therefore, the sample size, $n$, was calculated as:

$$
\mathrm{n}=\mathrm{z}^{2} \mathrm{p} \mathrm{q}
$$

$$
\mathrm{d}^{2}
$$

$\mathrm{n}=\left(1.282^{2}\right) \times 0.5 \times 0.5$

\section{$\left(0.05^{2}\right)$}

$\mathrm{n}=164$ wheat farmers

Stratified random sampling was used to pick the sample from the population. Wheat farmers were first grouped into two strata either as large scale farmers or small scale farmers. A systematic random sampling procedure was then used to identify farmers to be included in the sample from each stratum. The first farmer was picked randomly and thereafter a farmer was picked after an interval of 10 households.

\section{Data collection technique}

Data collection was done using a well structured questionnaire administered to the wheat farmers. Both open ended and closed ended questions were used in the questionnaire. A pre-test of the questionnaire was done in two Sub Counties namely Narok and Nakuru. This involved giving 15 questionnaires to wheat farmers in the two regions. This was done to ensure that the questionnaires were interpreted in the intended manner and any corrections deemed necessary were observed and adjustments made accordingly.

Both quantitative and qualitative data was collected for this study using well structured questionnaires. The data was collected by the researcher with the assistance of three research enumerators.

\section{Data analysis}

Data was analysed both descriptively and inferentially. The descriptive statistics was analysed by use of mean, mode and standard deviation and results presented using frequency distribution tables. The inferential statistics involved the use of binary logistic regression analysis, particularly the maximum likelihood ratio method. Logistic regression analysis was used to evaluate causality relationships between variables using the Statistical Package for Social Scientists (SPSS).

The Logistic regression model used took the form of;

$\mathrm{P}(\mathrm{Y})=\alpha+\sum \beta_{\mathrm{i}} \mathrm{X}_{\mathrm{i}}+\mu_{\mathrm{i}}$

Where:

$\mathrm{Y}_{\mathrm{i}}=1$ if success (respondent used pre-emergence wheat herbicides) and $\mathrm{Y}=0$ if failure (respondent did not use pre-emergence wheat herbicides) $\alpha=$ Constant term $\beta_{\mathrm{i}}{ }^{\prime} \mathrm{s}=$ Logistic coefficients for the independent variables $\mu_{\mathrm{i}}=$ Error term and $\mathrm{X}_{\mathrm{i}}$ 's $=$ Independent variables

\section{RESULTS, DISCUSSION AND CONCLUSION}

\section{Socio-economic characteristics of the respondents}

The results show that majority of the respondents $(69.70 \%)$ were male while $30.30 \%$ were female. The probable reason was that male was the head of households who controls most of the household's resources among the wheat farmers in Uasin Gishu County. The female wheat farmers on the other hand constituted the widowed, divorced and some entrepreneurs in Uasin Gishu County. A study by Kiprotich and Otieno, (2018) on the determinants of adoption and extent of seed care treatment of Home-saved wheat-seeds among smallholder wheat farmers in Kenya also found out that most of the respondents $91.1 \%$ were male while only $8.9 \%$ were female.

The study findings reveal that 50.80 percent of respondents had attained up to O' level, 19.70 percent had college / university level of education, 16.70 percent up to primary school and 10.60 percent had A' level education. Only 2.30 percent of respondents did not have any formal education. It is therefore seen that the wheat farmers sampled in Uasin Gishu County had formal education. That implies that the farmers were in a position to know about pre-emergence wheat herbicides and know how to use them in their wheat farming. This is further corroborated by Asrat et al. (2004) who emphasized that good education enabled farmers to understand use of improved technologies and apply it to achieve increased production.

The findings of the study show that 59.80 percent of the respondents were aged between 26 and 45 years. This was followed by the group of $46-60$ years with 21.2 percent of the respondents, the 25 years and below with 12.90 percent and the age group that had the least number of respondents was that of over 60 years with 6.10 percent of respondents. These results indicate that wheat farming is mostly carried out by the active section of the population in Uasin Gishu County. The results further imply that wheat farming is carried out by mature farmers who are capable of having the basic understanding of information regarding wheat farming and particularly the use of agro-chemicals that are required in wheat production. Getahun et al., (2000) said that the age of between 
30-49 years in a farming population, which was predominant in their study, implied that they are more active in their farms and are more receptive to agricultural extension programs.

The study showed that most of the wheat farmers were married $(65.91 \%)$ followed by the widowed $(15.91 \%)$, widowers $(11.34 \%)$ and lastly the singles $(6.82 \%)$. Wheat farming is laborious in nature and therefore practiced mainly by married people in order to provide sufficient domestic labor required during the wheat production processes.

Concerning the household size, results Table 1 indicate that the mean household size was 7 people. The minimum number of persons in a household was 2 , and the maximum was 20 people, with a standard deviation of 3.974. Based on the economic principle of demand and supply, the smaller the household size, the lower the overall household expenditure, thus letting households to devote more of their resources to farming including purchase of pre-emergence wheat herbicides. Due to lesser pressure of consumption needs per head, smaller families tend to have more disposable income and this is entirely in agreement with Mignouna et al., (2011) who found out that family with many members had little income left for spending in production investment unlike those with small household sizes.

According to the study results in table in Table 1, the average annual income of the farmers was Kshs. $10,581,040$ with a minimum of Kshs. 15,000, a maximum of Kshs. 300,000,000 and standard deviation of $39,328,561.77$. The larger the amount of disposable income available for use by each farming household, the greater the ability to purchase pre-emergence wheat herbicides and other inputs. This turns lead to improved management of wheat hazards brought in by pest and diseases; translating to increased yield per unit area of grown wheat crop.

Pertaining land size, the study results showed that the least land size amongst the sampled farmers was 1 hectare while the maximum was 2000 hectares. The mean land size was 80.19 hectares and the standard deviation was 265.995 hectares. Generally large tracts of land imply that wheat production involves mechanization leading to benefits of economies of scale. Mechanization leads to better efficacy and improved efficiency in use of agrochemicals. Therefore, land size would have an impact on the use of agro-chemicals. Monteshwe, (2006) noted in their study done in Ghana that land was associated with adoption of new technology, because wealthier farmers are better able to bear risks and thus are more likely to try new technologies.

Table 1: Socio-economic characteristics of the respondents

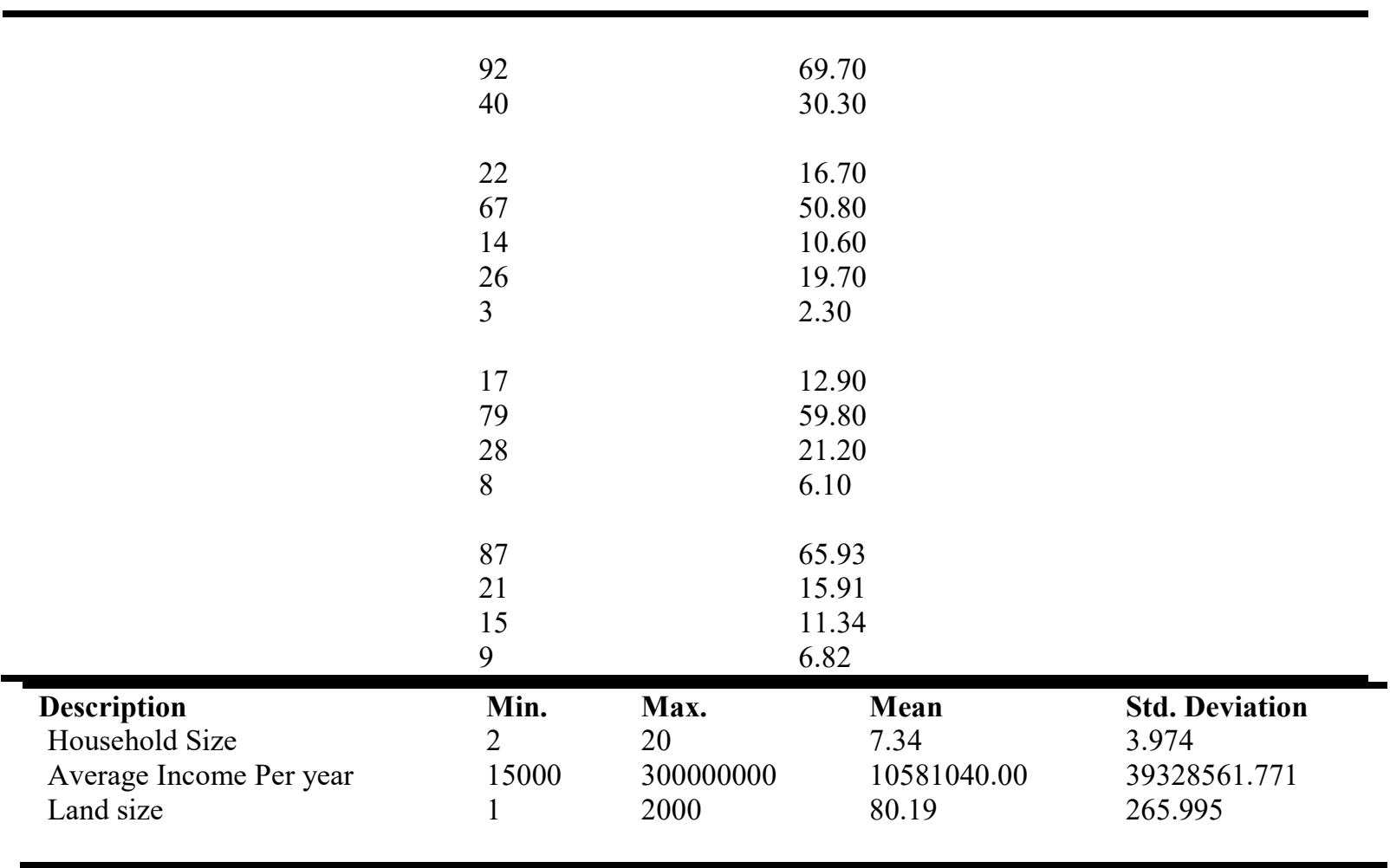

Source: Survey data, (2010)

Determinants of use of pre-emergence wheat herbicides

This section presents results obtained from Logit regression as well as discussion of the results. Table 2 presents a summary of the logit regression results of the study.

Logit regression results Table 2 indicated a positive and significant relation between use of pre-emergence 
wheat herbicides and education level at 1 percent. A unit increase in the level of education was observed to bring about an increase in the log of odds in favour of use of pre-emergence chemicals by 2.431 among wheat farmers in Uasin Gishu County. The positive relationship implies that people who are educated are more likely to use preemergence wheat herbicides in wheat production than those who are not since it is expected that the educated will know how to use the pre-emergence wheat herbicides as well as know the benefits of using agro-chemicals and indeed any other technology in wheat production. Therefore, they would adopt the use of pre-emergence wheat herbicides more easily than those without formal education.

Land tenure system also influenced the use of pre-emergence wheat herbicides in Uasin Gishu County. The relationship between use of pre-emergence wheat herbicides and land tenure system was seen to be negative and significant at 5 percent. The negative relationship was observed when land tenure system was leasehold. For leasehold, a unit change decreased the log of odds in favour of use of pre-emergence wheat herbicides by 4.293 among wheat farmers in Uasin Gishu County. That implies that for those who did not own the land on which they produced their wheat, they would probably not use pre-emergence wheat herbicides in their production. This is attributed to the fact that farmers who produce on leased land incur extra costs for leases and that curtails their production budget. Consequently, farmers end up using inadequate portions of inputs such as agro-chemicals or not using them at all so as to remain within their production budget. This affects the quality of their output and production and income from their farms is not optimized. It would therefore be necessary to encourage farmers who own land to intensify production of wheat. This would be enhanced, apart from farm visits, through extension services campaigns in print and electronic media to enlighten farmers on the benefits of producing on privately owned land. In the long run, this would promote the use of pre-emergence wheat herbicides by wheat farmers. It would also be necessary to ensure that government agencies involved with land registration make the process of acquiring the documentation necessary for obtaining private ownership of land is easy, accessible and timely.

Average annual income of respondents influenced the use of wheat pre-emergence wheat herbicides. The relationship between average income per year and use of pre-emergence wheat herbicides was positive and significant at 1 percent. A unit increase in average annual income brings about an increase in the log of odds in favour of use of pre-emergence wheat herbicides by 3.377 among wheat farmers in Uasin Gishu County. A positive relationship here implied that those wheat farmers who were able to have a larger amount of annual farm income would increase their usage of pre-emergence wheat herbicides due to larger capital outlays implied by larger incomes. Though the mean annual income for wheat farmers in Uasin Gishu District was Kshs. 10,581,040 it was observed that most of the respondents had annual income below average figure. These were respondents who engaged in small scale production. Those in large scale production were able to have higher incomes than annual average. The presence of extension services was also seen as having an impact on use of preemergence wheat herbicides by farmers in Uasin Gishu County. Similar adoption studies with same findings include the study by Doss et al. (2010) noted in their study done in Ghana that income was associated with adoption of new technology, because wealthier farmers are better able to bear risks and thus are more likely to try new technologies.

Presence of extension services and use of pre-emergence wheat herbicides had a positive and significant association at 1 percent. A unit change in the presence of extension services brought about an increase in the log of odds in favour of the use of pre-emergence wheat agro chemicals by 2.721 among wheat farmers in the County. This implies that extension services contribute significantly to the use of wheat pre-emergence wheat herbicides. However, though farmers said that there were extension services carried out in their areas, the frequency with which they were done was not satisfactory. It was reported that extension services were provided once in a year for most farmers. The extension services were carried out by agents from the Ministry of Agriculture, agrochemical companies and non-governmental organizations. Farmers were appreciative of the extension services noting that the information acquired through extension were very helpful. Therefore, providers of extension services should ensure that they increase the number of extension visits to farmers within a production period so as to keep track of farmers' progress and ensure that the right procedures were followed when using agro-chemicals. This is particularly important because new agro-chemicals keep being developed and one way to make sure that farmers use the right agro-chemicals in the right way and amount is through extension since it is the closest link between the farmers and research.

There was a positive and significant relationship at one percent between use of pre-emergence wheat herbicides and availability of wheat market information in Uasin Gishu County. A unit increase in the access to wheat market information brought about an increase in the log of odds in favour of use of pre-emergence wheat herbicides by 2.113 among wheat farmers in the County. This implies that a farmer with access to market information was more likely to use pre-emergence wheat herbicides than one without such information. Market information enables one to follow the latest developments in a particular industry and be able to know what is required in the market. In so doing, farmers are able to involve themselves in demand driven kind of production as opposed to supply driven production. A farmer will be in a position to know what varieties of wheat he can produce in his area as well as the agro-chemicals that best suit that variety. Thus a farmer is able to meet market demand and hence consumers are satisfied whereas a farmer gets to sell his produce thereby earning optimum 
income. It is therefore necessary to ensure that farmers have access to market information. This can be effected through extension services by both government and agro-chemical companies as well as through media and educative forums such as seminars and workshops so as to keep farmers informed.

The use of agro-chemicals requires a farmer to have adequate finances so as to purchase agro-chemicals sufficient for a full production period. Since wheat farming is practiced on large farms involving mechanized labour, a farmer needs to have sufficient income to sustain production. Inadequate income will require the farmer to seek extra funding through credit. This study sought to establish whether wheat farmers in Uasin Gishu County had access to credit from financial institutions. There was a positive and significant relationship at 5 percent between use of preemergence wheat herbicides and access to credit. A unit increase in access to credit brought about an increase in the log of odds in favour of use of pre emergent wheat agro-chemicals by 2.023 in the County. The implication is that farmers with access to credit were more likely to meet the cost of pre-emergence wheat herbicides and therefore use them in the right quantities. Farmers were of the opinion that the cost of acquiring wheat agro-chemicals was very high and therefore there is need to enable them meet these costs by having more accessibility to credit. This can be achieved by ensuring that financial institutions have less costly credit that can be advanced to wheat farmers. Further, credit access can be widened by having agro-chemical companies offer credit to wheat farmers for acquisition of pre-emergence wheat herbicides at fair rates to the farmers. This ensures that wheat farmers do not fail to use agro-chemicals or use inadequate portions due to the inability to purchase them. In the long run, this promotes the use of pre-emergence wheat herbicides.

Table 2: Summary of Logit Regression Results

\begin{tabular}{llcc}
\hline Variable & Coefficient & Standard Error & $\begin{array}{l}\text { Exp. } \\
(\boldsymbol{\beta})\end{array}$ \\
\hline Education Level & $2.431^{* *}$ & 3.276 & 7.572 \\
Household Size & 0.462 & 0.030 & 1.029 \\
Land Size & 6.322 & 0.003 & 9.163 \\
Land Tenure & $-4.293^{*}$ & 2.407 & 0.008 \\
Average Income & $3.377^{* *}$ & 0.439 & 9.431 \\
Extension Services & $2.113^{* *}$ & 3.215 & 8.159 \\
Market Info. & $2.796^{* *}$ & 3.528 & 8.273 \\
Credit Access & $2.023^{*}$ & 3.305 & 7.873 \\
Constant & -2.609 & 3.871 & 0.074 \\
\hline Source: Survey
\end{tabular}

Source: Survey data, (2010)

\section{Conclusions}

The findings of this study indicate that education level, an example of social factor, favoured use of pre-emergence wheat herbicides. It was observed that a farmer was more likely to use pre-emergence wheat herbicides if he / she had formal education than if he / she did not have formal education. Thus the null hypothesis that social factors had no effect on the use of pre-emergence wheat herbicides in Uasin Gishu County was rejected.

Land tenure system is an economic factor that influenced use pre-emergence wheat herbicides. The association between land tenure system and use of pre-emergence wheat herbicides was negative in the case of leasehold land tenure system. Other economic factors influencing the use of pre-emergence wheat herbicides were average annual farm income and access to credit. However, most of the respondents were in small scale production and had their farm incomes below the annual average and therefore their income was not sufficient to fund a season's supply of wheat agro-chemicals. Credit access also influenced use of pre-emergence wheat herbicides positively. Access to credit was particularly important in assisting the farmers meet the cost of acquiring preemergence wheat herbicides which was reported to be very high. The results led to the conclusion that use of preemergence wheat herbicides in Uasin Gishu County is influenced by economic factors and therefore the null hypothesis that economic factors had no effect on the use of preemergence wheat herbicides in Uasin Gishu County was rejected.

It was also established in the study that there are promotional strategies that would elicit positive impact in the usage of pre-emergence wheat herbicides in Uasin Gishu County. Provision of extension services, a promotional factor, influenced use of pre-emergence wheat herbicides positively. As a result, the null hypothesis that there were no promotional strategies that would elicit positive impact in the use of pre-emergence wheat herbicides in Uasin Gishu County was also rejected.

\section{Recommendations}

Wheat agro-chemicals are an important aspect of the inputs that are used in wheat production. It is therefore important to ensure that the usage of these agro-chemicals is enhanced amongst wheat farmers. In this regard, the following recommendations were made.

First, farmers in Uasin Gishu County with own-land should be encouraged to do wheat farming. In that 
connection also, government should ensure that the process of acquiring the necessary documentation for private land ownership is easy.

Secondly, wheat farmers should be encouraged to maximize their farm income from wheat by adopting modern technologies, and increase overall farm income, by diversifying their farming rather than relying on a single crop.

Thirdly, it is important for extension agents to increase the frequency of extension visits to wheat farmers since the farmers recognize the fact that the information gained from extension is very helpful.

Also, awareness should be enhanced through media and educative forums such as seminars and workshops so as to increase farmer access to wheat market information.

Lastly, accessibility to credit should be increased by having financial institutions offer affordable credit to the farmers and also having agro-chemical companies offer credit to purchase pre-emergence wheat herbicides and other agro-chemicals at fair rates to wheat farmers. It is also necessary to have further research on how extension services can enhance wheat production.

\section{Areas for Further Research}

As stipulated above, there is a necessity of looking into further research on how extension services can enhance wheat production. Various tenets of extension encompassing types of extension and extension targeting and segmentation of farmer aspects in light of this, needs to be looked into. For example advertisement needs to be looked at on its own merits, while farm visits and farmer trainings need to be given more re-emphasis.

A very glaring disparity in analysis of household income came out clearly during the study. It was found that $12 \%$ of farmers owned land areas above 80 hectares, while the rest were considered small scale farmers and had less household income. Average income was found to be Kshs 10,581,040 from farming accruing to households. There is need for further research in analyzing household dynamics of the small scale farmers alone, more since their number is expected to increase in future because of the expected population growth in Kenya. The findings will help predict future dynamics that will affect input purchase decisions by majority of farmers in future.

Seed care and seed quality also affect yield and therefore profitability of any crop. This needs to be given weight in future studies with an aim of understanding the current status of Seed care policies in Kenya regarding wheat and a possibility of improving this aspects. Seed quality policies and areas of improvement need to be given more emphasis in such studies.

\section{References}

Adebiyi, S., \& Okunlola, J. (2013). Factors affecting adoption of cocoa farm rehabilitation techniques in Oyo State of Nigeria. World Journal of Agricultural Sciences, 9(3), 258-265.

Asrat, P., K. Belay, and D. Hamito. (2004). "Determinants of farmers' willingness to pay for Soil Conservation Practices in the Southeastern Highlands of Ethiopia." Land Degradation and Development 15: 423-438.

Bahadur, K.L, (2004). Technology adoption and household food security. Analyzing factors determining technology adoption and impact of project intervention: A case of smallholder peasants in Nepal,Paper prepared to present in The Deutscher Tropentag to be held on 5 - 7 October, 2004, Humboldt-University, Berlin.

Baniya, B.K, D. Singh and B. sthapit, (2003). Factor affecting seed systems, Experience from Nepal, Nepal Agricultural Research Institute, Proceeding of Workshop, 16-20 September 2003, Pucallpa, Peru.

Doss, C.R., W. Mwangi, H. Verkuijl, and H. De Groote. 2003. Adoption of Maize and Wheat Technologies in Eastern Africa: A Synthesis of the Findings of 22 Case Studies. Economics Working Paper 03-06. Mexico, D.F.: CIMMYT

Feder, Gershon, Richard Just, and David Zilberman, (2015), "Adoption of Agricultural Innovations in Developing Countries: A Survey," Economic Development and Cultural Change.

Getahun Degu, M. H.Wilfred, Verkuijl, Abdishekur Wondimu, (2000). An Assessment of the adoption of seed and fertilizer packages and the role of credit in smallholder Maize Production in Sidama and North Omo Zones, Ethiopia.

Government of Kenya, (2010). Economic Survey, Government Printers, Nairobi.

Hassan, R.M., W. Mwangi, and D.Karanja. (2016). Wheat supply in Kenya: Production Inefficiency and Potential for Productivity Growth. CIMMYT Economics Working Paper No.93-02.Mexico, D.F.: CIMMYT http://www.fao.org/ag/agp/AGPC/doc/field/Wheat/africa/Kenya/kenyaagec.htm.

http://www.worldseed.org/cms/medias/file/TradeIssues/SeedTreatment/A_Tool_Sustainable_Agriculture_E N.pdf

Heckman, J., H. Ichimura, J. Smith and P. Todd (1998). Characterizing Selection Bias using Experimental Data" Econometrica, Vol. 66, September.

Khanna, M. (2012). Sequential adoption of site-specific technologies and its implications for nitrogenproductivity: A double selectivity model. American Journal of Agricultural Economics, 83(1), 35-51. 
Kiprotich W.B and Otieno S.J., (2019) " Analysis of Determinants of Adoption and Extent of Uptake of Seed Care Treatment of Home-Saved Wheat Seeds among Wheat Farmers in Kenya: A Double Hurdle Model Approach" International Journal of Humanities and Social Science Invention (IJHSSI), Volume 08, Issue 2, pp. 64-74, ISSN (Online): 2319 - 7722. Available online at www.ijhssi.org

Lai, P. C. \& Zainal, A.A (2015). Perceived Risk as an Extension to TAM Model: Consumers' Intention To Use A Single Platform E-Payment. Australia Journal Basic and Applied Science, 9(2): 323-330.

Loevinsohn, M., Sumberg, J., Diagne, A., \& Whitfield, S. (2013). Under what circumstances and conditions does adoption of technology result in increased agricultural productivity? A Systematic Review.

Mignouna, D., Manyong, V., Rusike, J., Mutabazi, K., \& Senkondo, E. (2011). Determinants of adopting imazapyr-resistant maize technologies and its impact on household income in Western Kenya.

Monteshwe, B, D, (2006). Factor affecting participation in mainstream cattle market by small- scale cattle farmers in Souse Africa, MSc Thesis, Department of Agricultural Economics, University of Free State, Bloemfontein. $118 \mathrm{p}$

Mugonozza ,S, G.T, 2001. Seed system in Africa, International center for agriculture research in the dry Areas. ICARDA.

National Seed Policy, Ministry of Agriculture, Kilimo House ,Cathedral Road,June 2010

Rahman M. S. and Haque Zerina. (2013). Adoption of Selected Wheat Production Technologies in Two Northern Districts of Bangladesh.Intl.J.Agril.Res.Innov.\&Tech.3 (1):2224-0616

Rogers, E. M. (2003) Diffusion of innovations, fifth edition. Free Press, New York, U.S.A.

Sikinyi E., O., (2010) Baseline Study/Survey Report on the Seed Sector in Kenya. Seed Trade Association of Kenya

Teklewold,H.,L.Dadi,A.Yami and N.Dana, (2006). Determinant of adoption of poultry technology: double-hurdle approach, Debre zeit Agricultural Research Center, Debrezeit, Ethiopia.

Uaiene, R. N., Arndt, C., \& Masters, W. (2009). Determinants of agricultural technology adoption in Mozambique. Discussion papers, 67. 